\title{
Reproductions, cultural capital and museums: aspects of the culture of copies
}

\author{
Gordon Fyfe* \\ Keele University
}

\begin{abstract}
The concept of cultural capital is well known in museum studies from pioneering visitor research conducted and reported by Pierre Bourdieu in the 1960s. This paper examines the concept in the light of the criticism that, whilst it illuminates the dynamics of cultural consumption and inequality in advanced capitalist societies, its socio-genesis is less well understood. It is argued that the historical sociology of fine art reproduction provides an opportunity to (i) enlarge our understanding of its formation and (ii) to explore the cultural character of the copy and the sociology of the body. The paper draws on Marx's concept of primitive accumulation, on Connerton's distinction between incorporated and inscribing practices and on Bourdieu's distinction between three states of cultural capital.
\end{abstract}

Key words: cultural capital, art reproduction, museums.

\section{Introduction}

The concept of cultural capital features widely in museum studies and in debates about access and social inclusion. Pierre Bourdieu's pioneering study of visitors, conducted in the 1960s, established its relevance for the museum although the concept has had a much wider sociological application than museum studies. In The Love of Art Bourdieu considers the puzzle that although public art museums celebrate citizenship and are open to all citizens only a relatively small and privileged proportion of people pass through their doors. His solution has three parts: (1) that museum visiting presupposes an aspiration which is the cumulative outcome of needs which are differentially inculcated via the inequalities of schooling; (2) that the key to unlock museum meanings, cultural capital, is socially and unequally distributed and (3) that schooling tends to reproduce inequalities of cultural capital from one generation to the next generation. ${ }^{1}$

In theorizing cultural capital Bourdieu describes a social world or space of 'semiotic struggle ${ }^{2}$ between groups in which the winners are those who succeed in converting their tastes into assets which have the appearances of being natural dispositions. What is distinctively sociological about Bourdieu's argument is that he interprets visitor statistics as expressing not the intrinsic attributes of tasteful individuals but as the measurable outcomes of historical struggles for possession of cultural capital. The means of decoding art are historical in character; amongst visitors only some possess the cultural capital that is required to decode the museum. What is distinctively Bourdieusian is an approach to inequality which proposes that classes make themselves through the medium, not just of economic struggles, but of cultural struggles for distinction. Thus, cultural assets are theorized not as merely derivative of other assets but as generative sources of power in their own right.

Some critics have observed that despite the sophistication of his analysis Bourdieu has too little to say about the socio-genesis of the market for cultural capital (e.g. Swartz 1997). Others have argued that despite making Marx the point of reference for the capital of cultural capital he loses sight of the relational character of capital as exploitation of labour (Calhoun 1993). Now, Bourdieu is not unaware of such matters although they tend to be marginalized and under theorized in relation to his substantive research on cultural inequality. As I explain 
below, in an important passage about the invention of writing, Bourdieu sketches the historical conditions of the socio-genesis of cultural capital and in a way which resonates with Karl Marx's thesis about economic capital and its so-called primitive accumulation (Bourdieu 1977).

Writing and perhaps printing provide points of entry into the study of the accumulation of cultural capital; so too does fine art reproduction. Bourdieu has rather little to say about reproductions of works of art. This is a surprising omission and for two related reasons. First, augmentation of cultural capital by museum visitors must surely partly depend on their consumption of photographic reproductions. ${ }^{3}$ Reproductions are, on the face of things, an important aspect of the formation of cultural capital in the visual arts for they are one of the means by which it is spread and differentiated. Secondly, contemporary art reproduction presupposes a photographic gaze, a habitus of the copy with implicit rules and habits of looking which orient the viewer to particular aesthetic priorities. The concept of habitus, with its emphasis on the way in which agency is embodied, is central to Bourdieu's cultural investigations; in this case it provides theoretical insight into how, in drawing on the implicit rules of photographic reproduction, individuals may be disposed to augment their cultural capital.

What is proposed here is that the accumulation of cultural capital through the photographic gaze presupposes a hidden labour of reproduction. In the nineteenth century that labour, which was not so well hidden as it is today, had a visible hand in the accumulation of cultural capital and a voice in the public sphere of art. This was the labour of the reproductive engravers who, prior to photography, specialized in handicraft reproduction and enjoyed a qualified status as artists. If, as I think we may, we interpret the development of the museum as one dimension of the twentieth-century accumulation of cultural capital then it came at a price-expropriation of the creative powers of artisan engravers. This leads to a question: what is the history of the hiding of the labour of reproduction and how was it linked to the objectification of the reproduction as cultural capital? Here I focus on two things: (1) the influential thesis of William Ivins concerning the effects of reproductive photography on the meaning of art and (2) the case of nineteenth-century English reproductive engravers who fought for recognition by the Royal Academy of Arts. This leads me to a more general discussion of the historical formation of cultural capital and the culture of copy. ${ }^{4}$ Finally, I show how the cultural status of the copy has significance for current debates about the place of the body in sociological theory.

\section{On the Primitive Accumulation of Cultural Capital}

Calhoun (1993) has pointed out that whilst Bourdieu draws on Marx's concept of capital there are some important differences from Marx in the way that the concept is deployed. For Bourdieu cultural capital is an asset that has been acquired; it enables people, collectively, to generate relations of distinction which are instituted as social or status hierarchies. However, for Marx, as Calhoun reminds us, economic capital was a relationship of exploitation. Bourdieu is well aware of this aspect of Marxist sociology but as Calhoun argues, he consistently theorizes cultural capital as a resource which yields power rather than as a relationship of power which yields a marketable resource (Calhoun 1993: 140). The point has been made (Swartz 1997: 289) that cultural capital presupposes a market in culture and that the socio-genesis of the market along with the compulsion to accumulate cultural assets warrants investigation. What seems to be missing in Bourdieu is an account of the socio-genesis of cultural capital, an account of its primitive accumulation.

Marx asked the question: what was the starting point of capitalism (Capital 1954: volume $1,667-715)$ ? It will be recalled that he took issue with those of his contemporaries who argued that the roots of capitalist wealth lay in abstinence and disciplined hard work. According to Marx these virtues only lead to accumulation if they are underpinned by capitalist social relations whose defining characteristic is free labour as opposed to the coerced labour of peasants or slaves. This was a matter of how labour came to be separated or 'freed' from ownership and control in the means of production. The answer was to be found in the abolition of serfdom: in the dispossessions that gave rise to the deserted village, the burning cottage, 
famine, the uprooting of rural populations, enclosures, clearances and migrations to the New World. ${ }^{5}$

So, are there historical moments when we may witnesses the formation of cultural capital and observe a thinning out of the normative order to reveal cultural expropriation and dispossession of the means of intellectual production? An answer to this question requires a closer anatomy of cultural capital and an appreciation of Bourdieu's account of its different modalities. Bourdieu distinguishes between three states of cultural capital: an embodied state, an objectified state and an institutionalized state (Bourdieu 1997: 46-58).

First, cultural capital is an embodied good; it is knowledge in the form of, for example, connoisseurship, artistic taste or some other disposition or faculty which can be acquired, accumulated and cultivated by individuals and which they may deploy as a resource, as an asset within a social space or cultural market (Bourdieu 1997). It is transmitted across generations by families whose class situation determines the amount of cultural capital accumulated through schooling, university education, through museum visiting or in some other moment or period of cultural consumption by an individual. Acquisition of cultural capital presupposes effort, labour and investment on the parts of individuals who compete for advantage within cultural markets.

The second state, which includes 'material objects and media, such a writings, paintings, monuments, instruments etc, may be transmitted as the ownership of things within and across generations (Bourdieu 1997: 50). It also includes inscriptions such as reproductions of art and artefact. Inscription is crucial to the formation of cultural capital. It is a means by which knowledge is lifted out of the locality and transmitted across time and space for consumption by individuals who may only encounter each other through the medium of inscription and who have incorporated the capacity to understand inscribed meanings.

The third state is that which is sanctioned and guaranteed in the form of, say, academic qualifications which can be exchanged and converted into other kinds of power such as economic assets. Institutionalization means that the holder of cultural capital no longer has to prove herself for the claim is guaranteed by, for example, the state as a prevailing authority over what counts as knowledge. In the case of the visual arts the public museum, with its collections, acts as guarantor of the value that is accumulated in the form of knowledge about art. In collecting, preserving and classifying things the museum acts selectively on the universe of objects to make public those cultural differences that count as original art and to suppress those that do not. Thus, cultural capital is not just accumulated by individuals, it is institutionalized by the state and its accumulation presupposes the guarantees of cultural monopolies such as academies, schools, universities and museums.

The significance of this tripartite distinction becomes clearer if we reflect on what is distinctive about cultural capital. Cultural capital refers to assets that have been emancipated from local settings such as those of traditional craft and craft monopolies. Assets which have been valorized as cultural capital are differently constituted from those of crafts where skills are embedded in the specificity of a task and perhaps regulated as trade mysteries under the restrictions of guild authority. What marks out cultural capital is not so much that it can be accumulated, but that it is fluid; it can be converted to other forms of capital such as occupational advantage or economic capital. It has the potential to flow out of localities and to cross the borders of trade, region and nation in the form, say, of universal academic qualifications. As Mike Savage points out the expertise of say, carpentry, is 'embedded in specific technologies and practical techniques that are unique to [that] physical production process....' ${ }^{6}$ The formation and institutionalization of cultural capital is therefore not only a matter of its individual accumulation and its monopoly by groups; there is also the matter of its origins and of its socio-genesis as an asset that remains durable from context to context. The accumulation of cultural capital presupposes the fluidity of relatively modern forms of objectification: of writing, printing and the reproduction of images.

Bourdieu observes that writing changes literature because it 'detaches cultural resources from persons [e.g. from bards]' (Bourdieu 1977: 186-87). Drawing on the anthropology of literacy, he observes that writing enables a society to move beyond the limits of a traditional culture of memory of the kind that we associate with poetry and with bodily capacities such as mnemonic techniques. It detaches memory from persons such as bards; 
it leads to a textualization of memory and permits the primitive accumulation of cultural capital in the hands of new kinds of specialists. These developments may be conceptualized as an impersonalization of power in the sense that the labour of cultural production becomes the divided property of a social network, a figuration or a field of production; powers of memory, communication and creation are abstracted from individuals and from the more immediate bodily powers of eye and hand. It is in this sense, then, that we can think of the primitive accumulation of cultural capital, for it entails the separation of traditional specialists from the determination of narrative or of pictorial meaning. It entails the extirpation of traditional rights.

Paul Connerton's distinction, established in relation to the study of social memory, between incorporating and inscribing practices, finesses our understanding of the usually hidden inner dynamic of cultural capital's accumulation. Incorporating practices are the bodily means by which memory is stored and recovered: for example mnemonics or the gesturing hand of the narrator. Clearly the accumulation of cultural capital depends in part on sedimentation of memory by means of rituals, for example the collective rote learning of the traditional classroom, which are culturally acquired and transmitted although they may also exist in personalized forms. Inscribing practices refers to means such as writing, printing, photography by which information is stored and which emancipates people from the local limitations of bodily powers and modes of communication. Connerton makes an important observation about the analytical nature of the distinction when he notes that inscription has an irreducible component of incorporation. Thus, whilst writing is a mode of inscription we may also regard it as an incorporating practice in the sense that there are habits of the hand which the writer may have acquired through disciplined exercise. In reading a letter we may receive the news but with a regard to the good hand that has formed the letters.

Drawing on Connerton I want to argue that mechanical and electronic forms of communication, whilst they may suppress the signs of incorporation continue to depend in some part on incorporated capacities for the effectiveness of their inscriptions. The example of reading may help to make the point. Many people may recall that at some point in their childhood they made the transition from reading aloud to silent solitary reading. That capacity to read silently and inwardly is a form of cultural capital that has been incorporated in childhood. The accumulation of cultural capital by means of silent reading presupposes inscription. It is an incorporated capacity which is facilitated by inscription, by skilled typesetting, layout and so on and which has been enhanced by technical development. Yet below the surface of social relations mediated by inscription is a hidden association between the incorporated capacities of silent reading and the incorporated practices of printed inscription. Incorporation and inscription may seem to go hand in hand but it is also possible to think of moments of looser association or even estrangement between them. The question is: what happens to incorporated practices when inscription lifts the memory of things out of the bard's control? Fine art reproduction helps us to understand what is at stake.

\section{Fine Art Reproduction with and without photography}

Douglas Crimp (1993) in considering the claims of photographs to be admitted to twentiethcentury art museums noted that the modernist ordering of art that is performed by the museum depends on something which does not appear at the museum but of which the museum bears the traces, namely reproductive photography. Reflecting on the artistic claims of photography Crimp observed that once photography enters the museum it threatens to disrupt the homogeneity of art.
...So long as photography was merely a vehicle by which art works entered the imaginary museum, a certain coherence obtained. But once photography itself enters, an object among others, heterogeneity is re-established at the heart of the museum; its pretensions to knowledge are doomed. For even photography cannot hypostatize style from a photograph (Crimp 1993: 56).

Crimp implied that the museum of art was formed through the medium of the expulsion of reproductions over which photography was granted authority. The culture of the modern museum is one of strong classification between originals and reproductions; the photograph 


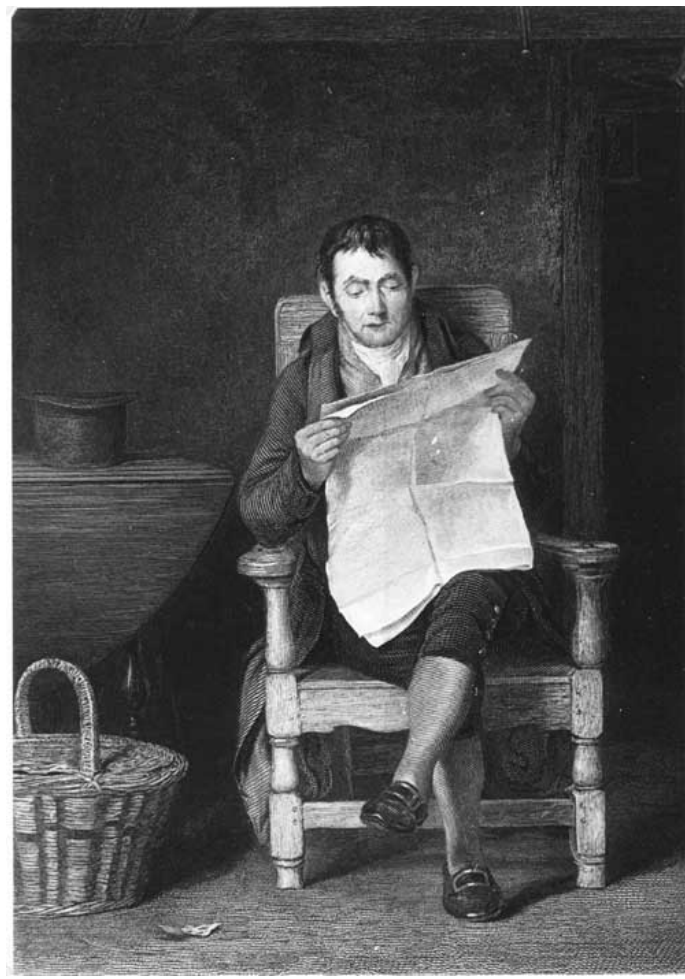

Figure 1. The Newspaper engraved by C. W. Sharpe (1818-1899) after Thomas Sword Good (1789-1872). Coll. author. entered the museum discretely as handmaiden to art whilst it was also denied the status of museum-worthiness, as art in its own right. Yet things were not always so clear for, before photography, there was a culture of the copy in which relationship between originals and reproductions were more visible. The point is not so much that there is hidden history of reproduction to be uncovered but that there is a contested history of the hiding of its claims to creativity. The homogeneity of the museum was in part a precipitate of largely forgotten nineteenthcentury struggles between two kinds of specialist - painters and reproductive engravers - who fought to determine the meaning of reproduction and the status of reproductive craft within the academy. What was at stake was the definition of the copy and what animated the struggle was the contested claim that the making of reproductions was a kind of authorship.

Reproductions of works of art have a particular status as objectifications of cultural capital because the moment of their consumption often invites questions as to what is present to the gaze, what is absent and how far the artist's intentions have been realized. The reproduced image is vulnerable to the charge that a complete meaning is absent or that the original meaning is subverted. At the museum the relationship between originals and reproductions is normally one that is strongly classified: reproduction is either back-staged through the concealed labour of authenticity (e.g. restoration and historical research) or sited, at the exit, as something that departs the museum as a post card.

We do not usually expect our reproductions to be signed or to have the identities of technicians and photographers identified. Authorship in reproductions is anonymous. Kenneth Clark's directorial plaudit in 1938 on behalf of the photographer for his One Hundred Details from Pictures in the National Gallery is surely unusual (Clark 1938/1990). ${ }^{7}$ However, this breach of convention may remind us that there is an absent or repressed authorship in reproduction and that the museum visitor's incorporation of cultural capital by means of the photographic inscription presupposes the incorporated labour of inscription.

Most deliberations about art reproductions assume that they are photographs or rather that they are mechanical or digital reproductions of photographs. However, photography did not inaugurate the age of art reproduction. The mass production of reproductions was an established feature of the art trade before photography and well before the mechanical reproduction of half tone photographs ${ }^{8}$ arrived on the scene in the late nineteenth century. In other words the idea that photographic reproductions displaced an earlier, more authentic visual culture of communion with originals is a myth. Photography, or rather the mechanized production of photographic reproductions, displaced not originals but an earlier culture of the reproduction that was rooted in handicraft-print making.

Throughout the eighteenth and nineteenth centuries reproductions ideally, but not necessarily, took the form of line engravings. In a pre-photographic age, works of art might be known as reproductions engraved in line: 'pictures interpreted by engraving, had become engravings' (Malraux 1967: 11-12). The reputations and fortunes of successful artists, 


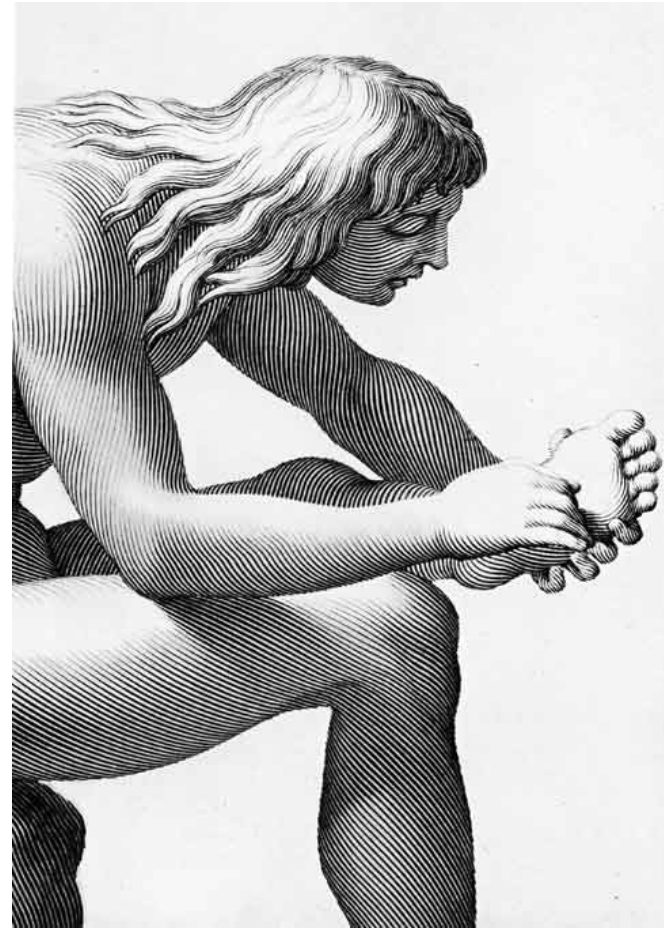

Figure 2. Portion of an engraving of 'The Spinello' by Baudet (c. 1636-1678). Half tone illustration from Prints and Visual Communication. 'As a stunt, it probably bears much the same relation to draughtsmanship that Paganini's playing on one string did to music' (Ivins 1953: xvii). particularly those of painters and sculptors were heavily dependent on a lucrative trade in engraved reproductions of their works. Malraux asks: what prior to 1900 had connoisseurs seen? 'They had visited two or three galleries, and seen reproductions of a handful of the masterpieces of European art; most of their readers had seen even less' (Malraux 1967: 15-16).

Viewed from contemporary photographic and digital perspectives, handicraft reproductions tend to appear either as impoverished and technically inadequate reproductions or as virtuoso performances that have a certain antiquarian interest, but have little to tell us of substance about the work of art. We may appreciate what they tell about style in terms of subject and the composition along with its literary and classical allusions. But style as it might be realized in the medium in, say, the handling of paint, is absent. Rather, it is the style of the engraver that commands our attention as the gaze switches between the two authorships and in a way that is hardly invited by modern reproduction. (Figure 1.) However much we may be concerned to remind people of the difference between museum originals and contemporary photographic reproductions the superiority of the camera over the burin ${ }^{9}$ would not be conventionally in doubt.

However, I want to suggest that we think in a less judgemental, less modernist and more appreciative way about the reproductions of the past. An appreciation of their significance requires us to think in a less teleological way about how technical change, modernism and the copy were interwoven. Prior to photography there was a different culture of the copy to that of our own and it was one which assigned a creative role to the reproduction of art. Thus, reproductions carried the evidence of their authorship in the demonstrable skill with which engraved effects had been achieved and in the ritual signs of authenticity which populated the margins of the plate. Handicraft reproductions showed the signs of the labour of their making whilst their consumption was linked to an appreciation of the incorporated powers of expression associated with the engraver's style and skill. Correspondingly, consumption of reproductions of art, qua reproductions, provided for a classical connoisseurship and for its cultivation and incorporation as cultural capital.

By the twentieth century photo-mechanical methods were established as the dominant way of reproducing paintings but this was the final chapter in a protracted and contested story of technical and organizational change. This was a battle in which reproductive crafts-people fought to preserve the incorporated powers of expression associated with their trade and in which they were ultimately defeated. It was also a process which was interwoven with the institutionalization of modernism. The photographic gaze differed from the engraved gaze because it created the illusion of communication without mediation; it brought the work of art and the signs of its making into the presence of the viewer whilst it suppressed the incorporated practices of print-making which made that presence possible. Between the 1750 s and the 1850 s the instruments of reproduction were gradually transformed beyond the 
limits of the artisan print maker. The last gasps of the reproductive engravers' resistance are perhaps to be found in the closing chapters of late nineteenth and early twentieth-century business histories, trade journals and the archives of trade unions. Here, one finds scattered, half submerged, evidence of attempts to control the instruments of reproduction and to keep them within the limits of bodily labour, knowledge and skill.

There are two aspects of social change and art reproduction which require emphasis at this point in the argument. First, the virtues of photographic reproduction did not automatically present themselves; some nineteenth-century connoisseurs lamented the passing of handicraft engraving up to the turn of the century and on the grounds that it entailed a creative interpretation or translation of originals. ${ }^{10}$ Secondly, an accumulating body of research suggests that there is a repressed historical relationship between the art museum and the reproduction. It points to an entanglement of art and reproduction whose histories cannot be easily separated and whose relationship belies the simplicity of the art that is before and the reproduction that is after. The histories of art

4 pour ance les fointsfe les traits gros et delies 4 jumant les Occácons
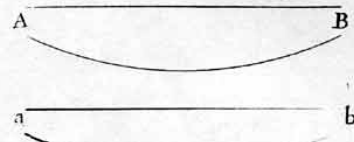

b
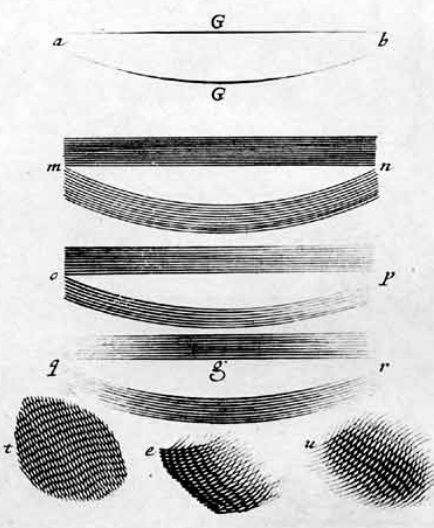

Figure 3. A page from Bosse's

Treatise on Engraving of 1645.

Reproduced as a collotype in Prints and Visual Communication. 'Showing exercises for the beginner in the use of the engraver's and etcher's tools' (Ivins 1953: xv) history and photography (Bohrer 2002, Hambler 1995, Roberts 1995, Sousloff 2002) provide evidence of complicity, of mediation and of photography's role in shaping visual habits that were attuned to modern art worlds. There is some evidence, not just that the twentieth-century culture of the camera consolidated a photographic way of seeing, but that new habits of modernist looking cued the camera.

Thus, an aspect of the modernist revolution is that reproduction slipped out of sight and behind the charismatic authority of the artist. Modernism entailed a separation of academic painters from the dominant means of intellectual production. However, the institutionalization of modernism was interwoven with the separation of reproductive engravers from cultural authority for it went handin-hand with a stigmatization of the copy which lost its public and pedagogic function whilst its skilful making was distributed within the culture industry, back-staged and 'black-boxed' as mere 'reproduction.' The accumulation of cultural capital in art presupposed confiscation of the handicraft engraver's powers of expression.

The following three sections of the paper pursue these matters by means of a closer examination of the pre-modern world of reproductions. First, there is the system of handicraft engraving that came to be known as line engraving. Here I draw heavily but not uncritically on the seminal work of William Ivins in order to provide a picture of the language, or discourse, of pre-photographic reproduction. However, nineteenth and twentieth century changes in the culture of the copy were not merely discursive changes. The culture of the copy was a contested culture in which the meaning of reproductions was increasingly a matter of intra-professional dispute between painters and engravers. Thus, secondly, I examine a power struggle which took place between painters and engravers over the academic status of the latter. The conflict between painters and engravers is an historical moment in the suppression of heterogeneity that it is marked by a transformation in cultural capital. Thirdly, I argue that these changes in reproduction, of technique and of status, are part and parcel of the socio-genesis of twentieth-century cultural capital. The work of Ivins provides a means of understanding the nature of that development. 


\section{William Ivins and the reproduction of art}

William M. Ivins Jr (1881-1961) was a print curator. His ideas about visual communication had an impact beyond the Metropolitan Museum of Art in New York where he held a post from 1916 until his retirement thirty years later. In Prints and Visual Communication $(1953)^{11}$ he advanced a seminal thesis concerning the difference that photographic reproductions had made to art. The distinctiveness of Ivins's contribution to understanding photographic reproduction flows from his insights into the marginalization of a connoisseurship associated with handicraft reproductive prints.

Two concepts are central to the Ivins thesis: viz. the exactly repeatable pictorial statement and visual syntax. The first signals the importance of the printed image for science, technology and mass culture as well as for art: 'far from being merely minor work of art, prints are among the most important tools of modern life and thought' (Ivins, 1953: 3). The invention of

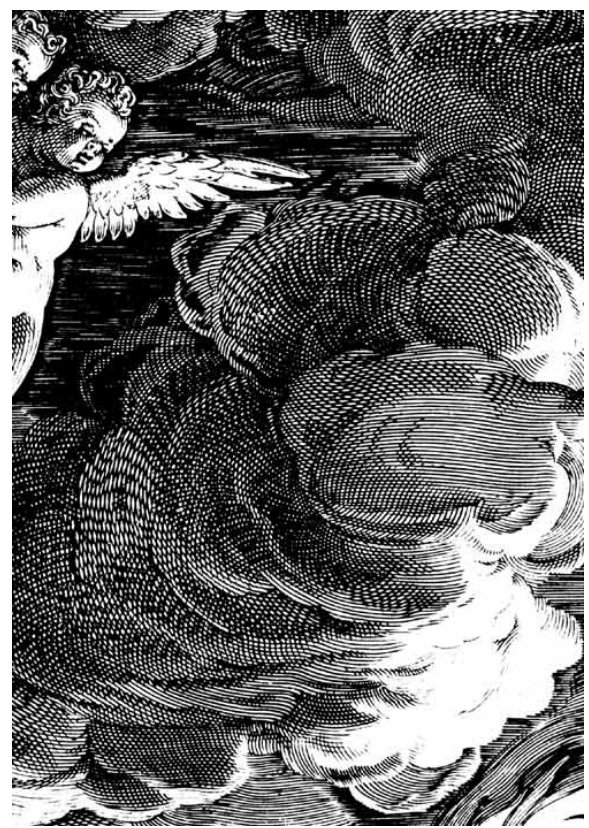

Figure 4. Portion of an engraving by $\mathrm{C}$. Cort (c. 1530-1571) after Titian.

Reproduced as a collotype in Prints and Visual Communication. This shows 'how a stylist engraver took pleasure in weaving a linear web' (Ivins 1953: xv). the exactly repeatable pictorial statement emancipates knowledge from face-to-face settings and elevates the production of images above the vagaries of hearsay. The concept of visual syntax specifies the discursive aspect of reproductions. As printed images reproductions are characterized by syntactical forms, depictive conventions. Ivins showed how early sixteenthcentury engravers devised visual conventions for making printed images. Print-making, which was hegemonized by painting, was charged with representing the world according to a classical ordering of things. The matrix or plate used in this process was created by ploughing lines into metal with a specialist tool such as a burin. Line engraving, Ivins shows, was a technique by means of which painted and drawn images were transposed into a secondary language of line.

This language of engraving enabled artisans, as it were, to perform reproductions. The painting or drawing was recomposed by means of a system of lines and dots into a printed image. Ivins provided many illustrations ${ }^{12}$ in support of his argument, almost all of which were from the collections of the Metropolitan Museum. They included demonstrations of the linear mode of depiction that had been systematized in the seventeenth century (Figure 2.) This was a schema which permitted a degree of creative intervention but within the parameters of calculated linear reproduction. For Ivins it belonged to a lost, but to him unlamented, tradition of print making. Amongst its forgotten artists was Abraham Bosse, a page of whose Treatise on Engraving Ivins reproduced (Figure 3.)

The artisan's linear scheme provided knowledge of iconography and composition rather than an understanding of the 'personal characteristics of the original works of art, their brush strokes and chisel marks' (Ivins 1953:166). The meaning of a work of art was interpreted as [t]he engraver's language: '[p]ainstakingly as Durer might copy a real rabbit ... in his own syntax, when it came to copying a print by Mantegna he refused to follow Mantegna's syntax, and retold the story, as he thought, in his own syntax' (Ivins 1953: 61). What was invisible to the gaze was the authority of the original artist as registered in the quality of the medium and the painterly gesture. What was visible in the signs of craft was the authority of the reproductive engraver. The engraver-as-interpreter occupied and sought to defend a space that was, in the twentieth century, to be closed off by photography, a space of connoisseurship between 
original work of art and reproduction (Figure 4.) Engravers 'chose the pictures they were to... reproduce not for their merits but as vehicles for the exhibition of their particular skills' (Ivins 1953: 69).

The laying of lines, swelling and diminishing, the creation of webs of crossed lines, of lozenges with little flicks and dots in their middles the making of prints in lines that all ran parallel or around and around - one engraver made a great reputation by the way he rendered the fur of a pussy cat, and another made a famous head of Christ that contained but one line, which beginning at the point of the nose, ran around and around itself until it finally got lost in the outer margin (Ivins 1953:69)

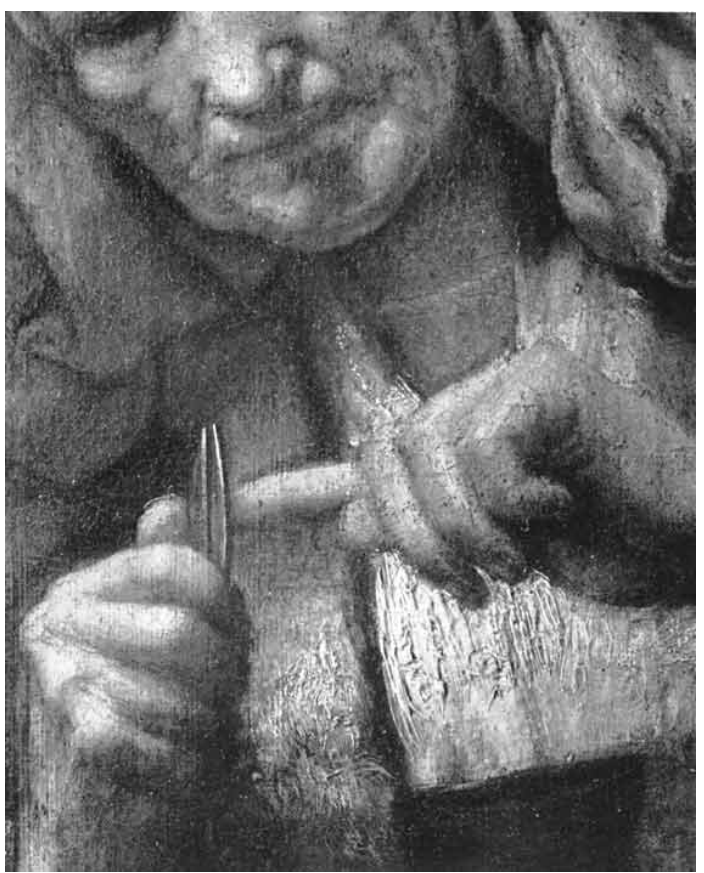

Figure 5. A half tone after a photograph of a detail of Rembrandt's painting, 'An Old Woman Cutting her Nails'. Reproduced in Prints and Visual Communication. Ivins emphasizes that 'the actual surfaces of the object reproduced are now made visible' (Ivins 1953: xxv).
Secondly, engraved reproductions invited a connoisseurship that was sensible of an authority that resided not in the picture but elsewhere - a hypostatization of something that lay behind the engraved lines, the "unreachable, the unknowable, vrai verite' (Ivins, 1953:139). Ivins recites the vocabulary of eighteenth-century neoclassical doctrines: 'harmony, proportion, dignity, nobility, grandeur, sublimity' to indicate the discursive preoccupations of connoisseurs who depended on reproductive engravings. Here there was no knowledge obtained of '[t]he wilful theatrical stroke of Rubens's brush' or 'the dominant expressive gouge of Michael Angelo's chisel' (Ivins 1953:173).

It was by means of photographic reproductions that the connection between the medium and the creative intention of the artist could first be widely experienced: the 'traces of the creative dance of the artist's hand' and the effects of 'a deliberate creative will' (Ivins 1953:144). Photography made possible the transmission of images as modernist art. It enabled people to see 'the choice and manipulation of the paint', the difference between the founders of modernism and the Salon subject painters of the nineteenth century (Ivins 1953: 144). Ivins demonstrated the argument with a half-tone detail from a museum masterpiece, a painting by Rembrandt (Figure 5.) For Ivins the certainty that is established in this half-tone is to be compared with the uncertainty of pre-photographic reproductions of a classical masterpiece. (Figure 6.) He also presented ten reproductive engravings after the Laocoon (made between 1520 and the 1890s). According to Ivins the meaning of the sculpture is distorted, fragmented and dispersed as it is refracted through the syntaxes of different engravers. By contrast, as evinced by the Rembrandt half tone, the photograph brings art into our presence because the syntax of reproduction drops below the visual threshold of the viewer (Ivins 1953: 177).

the lines of the process as distinct from the lines of the visual report could be below the threshold of human vision. In the old hand-made processes the lines of the processes and the lines of the report were the same lines, and the process counted for more than the report in the character of the lines and the statements they made (Ivins, 1953:177, my emphasis). 


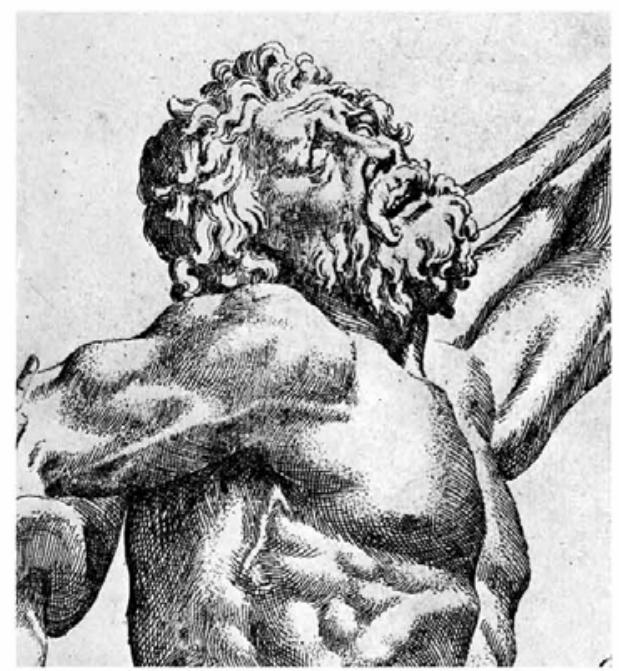

(a)

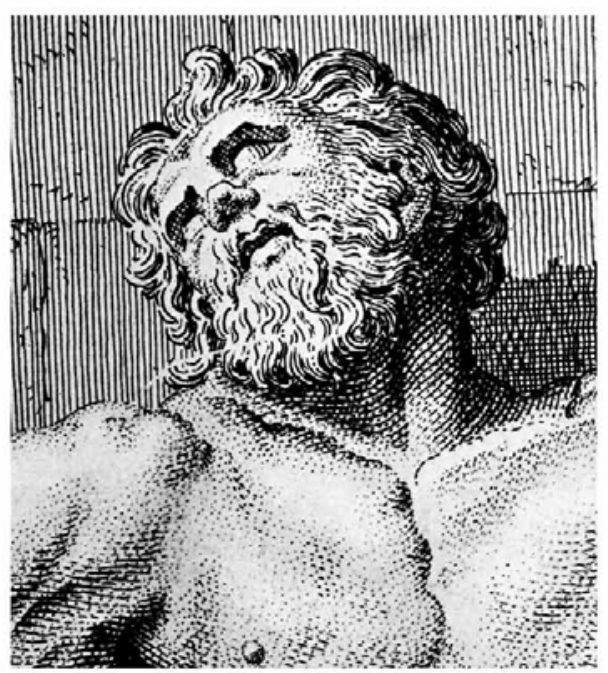

(c)

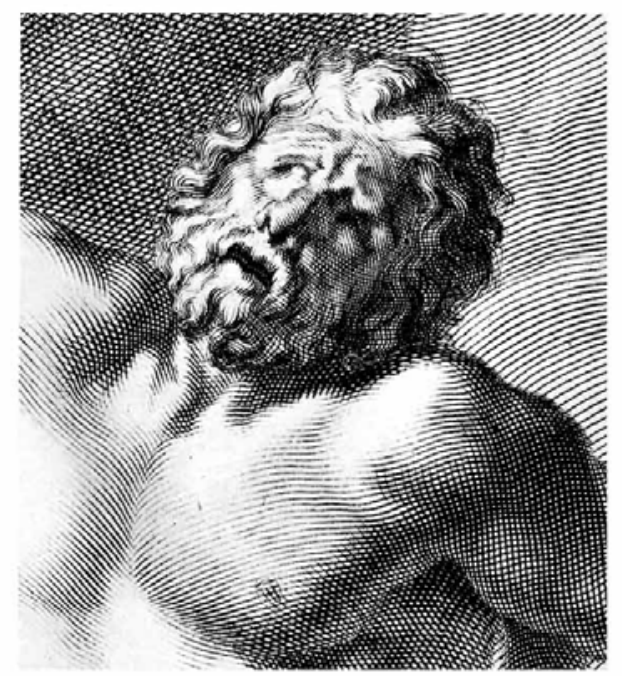

(b)

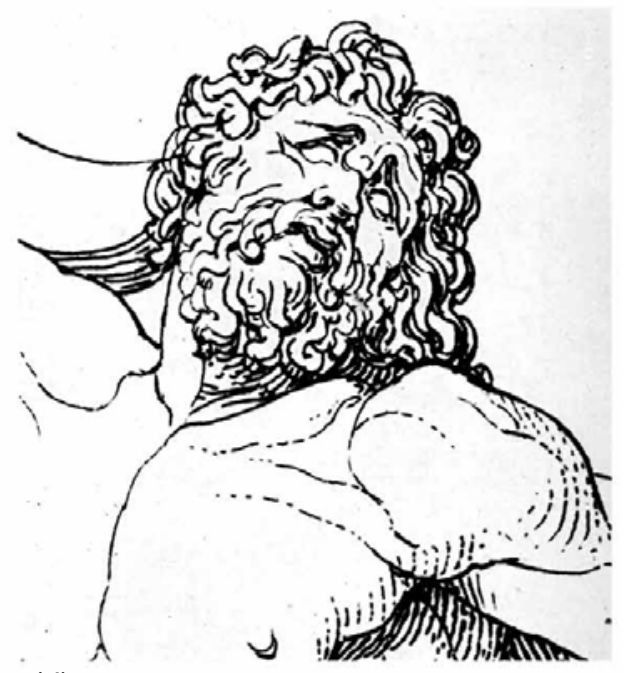

(d)

Figure 6. The head of Laocoon. Four of Ivins's selection of ten engraved reproductions of the canonical classical work of art. Reproduced as half-tones in Ivins's book.

Photographic reproductions suppressed the signs of handicraft in the production of reproductions. The dots produced by the half-tone screen are interpreted as continuous tone. It is the quality of the lens not the interpreter that matters when it comes to photographic reproduction (Ivins 1953: 138). The camera objectively draws art lovers into a communion with image-as-a-work-of-art; it is for Ivins visual communication without syntax.

Ivins's was not a disinterested account of his subject. It is surely no accident that he had troubled relations with his colleague and fellow curator of Greek and Roman Art (Tomkins 1970:241). Ivins was implicated, both as a writer and a curator, in the dissemination of a modernist frame of reference and the suppression of the classical gaze. His was a modernist aesthetic in the sense that Bourdieu (1984) and Hetherington (1999) mean when they speak 
of a gaze that is emancipated from things in the world. Ivins's was the Kantian gaze that is invited by the modern museum to spend time in an ordered inner reflection that eschews the noumenal word. Thus the half-tone permitted appreciation of a formalist concern with style, with painterly qualities, with the presence of the artist's touch in the materials and so on. In learning to see photographically what people began to see was the difference between art and mere illustrations of things in the external world. The photographic reproduction was both an objectification of the connoisseur's distinction between art and mere pictures of things and a means through which the senses were ordered within the viewing subject (Hetherington 1999).

\section{The Engravers}

Although I am using the case of English art institutions to develop my argument we should not see English events as unique..$^{13}$ By the eighteenth century specialists in reproduction formed distinct strata within European art worlds; they performed closely related functions for different but interdependent cultural producers and they were agents in the cycle of accumulation that formed collections and museums. In the service of patrons they reproduced the material culture of patrimonial power; they disseminated images of antiquity and they serviced the trade in reproductions of antiquities. Engravings spread news of royal, aristocratic and institutional collections and formed a part of the visual propaganda machines of European states and their rulers.

Painters built their reputations in collaboration with publishers and engravers of reproductions. The so-called Golden Age of the Victorian living painter was, at least in part, the Golden Age of the nineteenth-century engraved reproduction (Figure 7.). Depictions of workshops, tools and working practices often displayed the

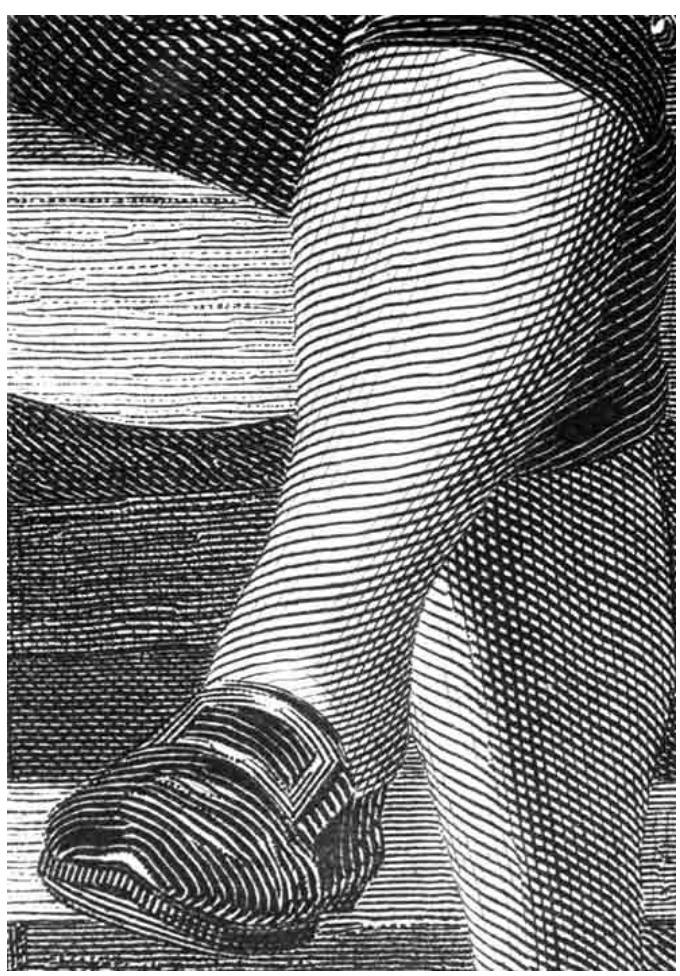

Figure 7. Detail of The Newspaper, engraved by C.W. Sharpe (1818-1899) after Thomas Sword Good (1789-1872). Coll. author aspirations of a liberal and honourable trade with the classical associations of academic training and studio practice. Endurance, labour and the skills of making reproductions were also celebrated in the periodical press and elsewhere. (Figure 8.). The hand of the engraver as it grasps the tools of craft appears in depictions of engravers' shops as a connotation of the embodied power of skilful labour. (Figure 9.) Written reports provide their readers with narratives of heroic, sometimes disabling, labour and make references to a skilful creation which presupposes capacities quite different to those of modern art. The lines, dots and flicks of the engraved plate were a sign of the hand that had left its signature in the reproduction.

By the early 1800 s the situation of engravers was being transformed in several key respects. First, there is the question of academic status. In the case of London's Royal Academy of Arts (RA), which was established in 1768, engravers had a qualified status as artists. They were excluded from participation in the RA's government and denied the cultural authority that some of them sought. Discontent about their status lead a number of engravers to challenge the RA, almost from the moment of its institution, and their protests figured in Academic politics well into the nineteenth century (Fox 1976, Fyfe 1973/2000).

Secondly, there is the situation of the engraver within the world of commercial 


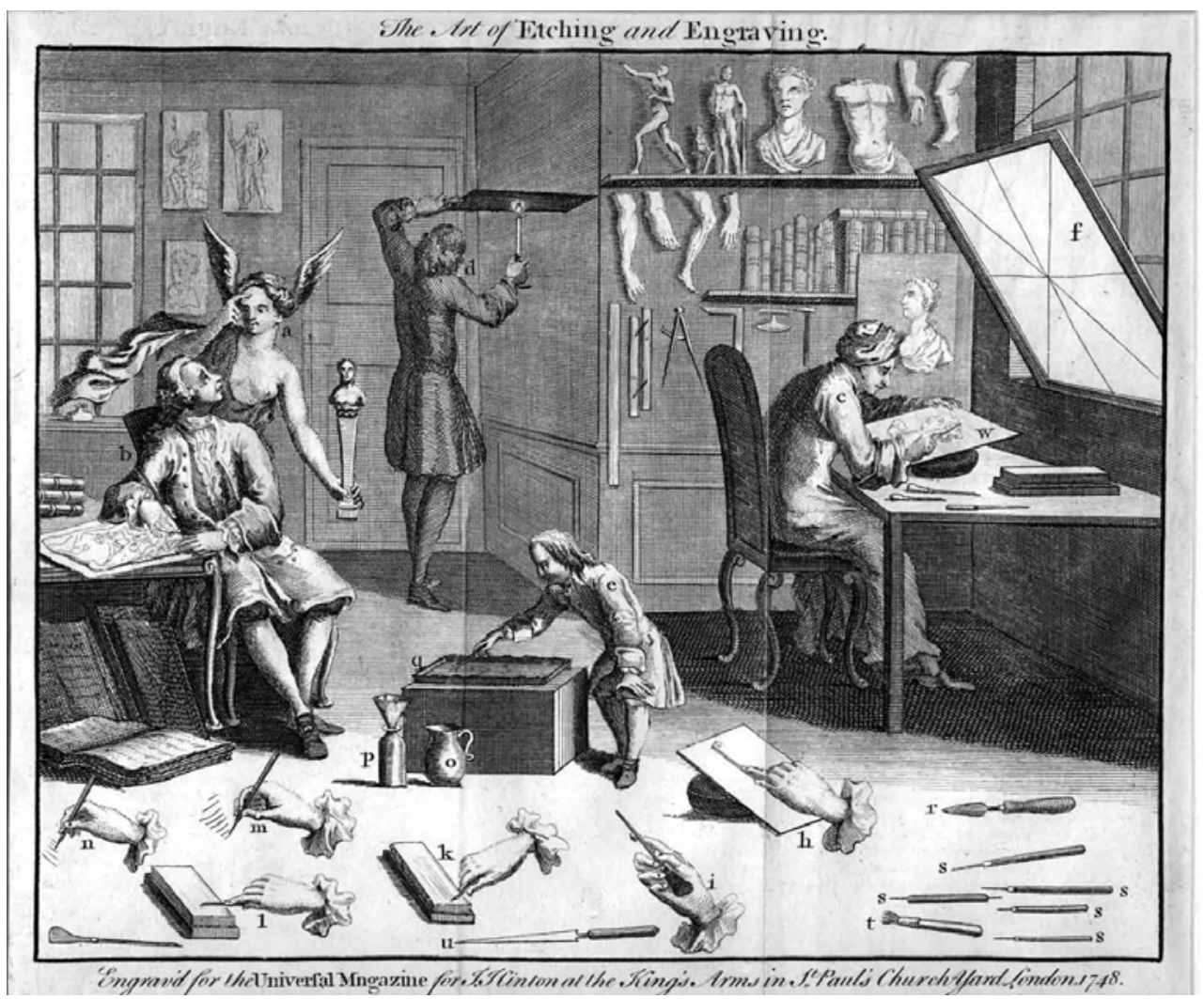

Figure 8. An Engraver's Shop; from the Universal Magazine 1748. Coll. author

production. Here it is a matter of changes which isolated many engravers from the intellectual means of production. Throughout the eighteenth and nineteenth-centuries the relationship between painters and engravers was changed by innovations in the techniques of reproduction and the organization of labour - innovations which were aimed at perfecting engraving's capacity to report the values of other media. Some engravers mutated into capitalist employers and publishers, whilst others were converted to semi-skilled labour These things, which were deeply implicated in the transformation of the engraver's social identity and reputation as an 'artist' were the characteristic ones of nineteenth-century deskilling..

Thirdly, engravers experienced the foundation of the RA as a humiliation. The sources of their humiliation were in the development of a fine art politics from which they were progressively excluded and in the development of a concept of creativity, ultimately that of modernism, that eluded them altogether. Engravers challenged the RA and its categorization of them as mere copyists. The RA's position was that to admit engravers on equal terms would not be commensurate with 'the dignity of the Royal Academy' and the nature of Art. Engravers were denied originality. The engravers' response was grounded (Landseer 1807; Pye 1845) in a distinction between copying and translation; their claim was that engraving was an intellectual activity, a form of translation which bore comparison with poetry. ${ }^{14}$

John Pye (1782-1874) was amongst several nineteenth-century engravers who elaborated their case in book form. Pye's Patronage of British Art (1845) is, in part, an account of how, to his mind, the RA severed its association with trade mutuality, betrayed its public obligations to British patronage by pursuing the interests of a section of the artistic community and became a monopoly without a moral base. Pye's is an artisan's narrative which captures moments of expropriation: his burnished footnotes, his full-bodied end-notes, his meticulous diagrams are as crafted as any copper plate. Pye is the artisan who holds that the RA, in its 
very institution, took away those things which belonged to the collective body of British artists. For Pye academic treatment of engravers was part and parcel of the RA's erasure of the past glories of reproductive engraving and of its independent craftsmanship.

Pye's writings and those of others register the making of a culture of the copy that is at odds with the engraver's habits of mind and self image. They reproduced the paintings of the Old Masters and English contemporaries as handicraft prints: they had their place in a hierarchy that was sanctioned by a waning estate system of cultural authority - the chain of being, the dispositions of patronage. In collaborating to visualize the world painters and engravers both had their places and their proper role within the scheme of things. Yet they were being drawn into a world which would dissolve hierarchy in the market and measure everything from an authorial centre, from the singular authority of the artis t-as - creator. Engravers would come to be measured by what they

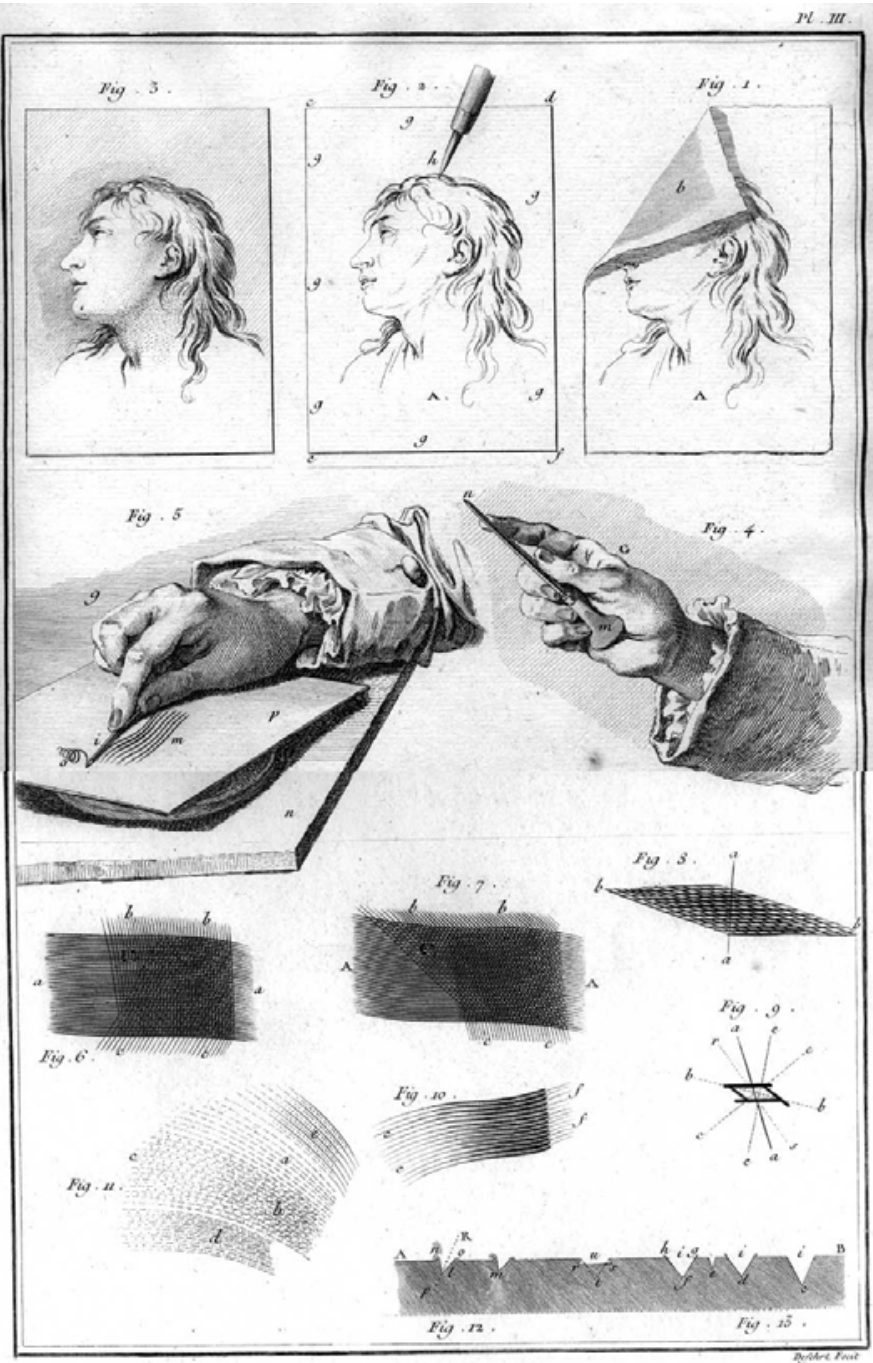

Gravure in Taille-douv

Figure 9. Gravure en Taille-douce from Diderot's Encyclopedie. Coll. author

lacked and that lack would be originality. They fought to retain a place within the cultural apparatus, but the fight was conducted on a terrain that was increasingly defined by a photographic way of seeing (Fyfe 2000, Jussim 1983).

\section{Reproductive Engraving, Cultures of the Copy and Cultural Capital}

The engravers' battle is well-documented in the annals of nineteenth-century art politics (Fox 1976, Fyfe 1973/2000, Hyde 2002, Gage 1989). It significance has, however, been underestimated; the episode has been treated as a sideshow to the main events of art history and dismissed as being of little more than antiquarian interest. This is partly because the world of Victorian reproduction has been refracted through modernist priorities which consign handicraft print-making to the evolutionary past of modern photographic methods. However, 
we should remind ourselves that nineteenth-century engravers inhabited a culture of the copy which had different priorities to those of modernism. The handicraft engraving was not a half finished reproduction any more than Australopithecus was ever a half finished human being. Line engraving was fit for its purpose; it was the basis of a complete system of copying images which functioned satisfactorily within a pre-modernist art world.

Reproductive engraving, in the form of line-engraving, was pre-eminently an academic mode of reproduction grounded in classical norms which regarded imitation as way of realizing the ideals of Nature. Imitation was emphatically not copying, although copying had a determinate role within the academic curriculum. Classical art sought clarification of Nature's order by seeing the through the imperfection of particular things to a universe of ideal forms (Honour 1972). Thus the painter aimed through careful training, to see, depict and imitate a beauty that was abstracted from the concrete everyday world. Just as the painter might study antiquity, so too the engraver might imitate an original; but what is different in comparison with the modern copy is that the classical culture of the copy made it possible for the engraver to enhance the original by correcting the artist in the light of Antiquity. If the classical or academic artist revealed the order that God had created in Nature, then the reproductive artist, appropriately imbued with an understanding of the classics, history and the great masters, had a determinate role to play in realizing the truth of Nature. It should not, therefore, surprise us if the engraver found it necessary to make the odd correction (Anon 1770: 1). The engraved reproduction was not so much a McLuhanesque medium which determined what could be known about art as it was a medium through which classical norms were realized and the means by which the implicit rules of looking found their justification. There really was something, unreachable and unknowable, a world that lay behind the engraved lines.

A growing body of writing in the humanities and the social sciences has focused on the cultural significance of the copy and has challenged the characteristically modern and western tendency to reify originality by opposing it to the denigrated copy. ${ }^{16}$ Fisher (1991), Krauss (1986), and Taussig (1993) are amongst those whose work, whilst suggesting the need for a relational rather than antinomian appreciation of originals and reproductions, also points to the agency of copying and to its functional significance as social reproduction. Indeed, as Fisher (1991) argues, copying is a necessary making; whilst in modern usage it may often connote waste there is an older traditional sense that the most remarkable thing that nature does is to produce copies (Fisher 1991: 100).

These writings invite fundamental questions about copying and cultural classification and, more generally, about human attributes and their social organization. They also invite interdisciplinarity. Bourdieu (1984), Elias $(1978,1982)$ and most recently Shilling (1993) are amongst the most ambitious attempts to move sociology beyond the turf wars of biological determinists and social constructionists. The concept of habitus, as deployed by Bourdieu and Elias, has been important here. As Shilling points out, the significance of the concept is that, in specifying the socially acquired but automatic dispositions through which people are oriented to others, it provides a means of conceptualizing the process by which natural bodies are transformed into the social facts of second natures. The concept directs sociological attention towards the most casual, apparently insignificant natural aspects of human embodiment in social settings -the glance of civil inattention or the gaze of the connoisseur. It provides theoretical precision for Ivin's observation that, in the twentieth century, people forgot that that they had learnt to see things photographically even in the absence of photographs:

...fifty years ago most of the 'shots' of Michael Angelo's sculpture that were shown in the movie called The Titan, would have been decried for their distortion. But today they are praised. ...the photograph became the norm for the appearance of everything. It was not long before men began to think photographically, and thus to see for themselves things that previously it had taken the photograph to reveal to their astonished and protesting eyes. Just as nature had once imitated art, so now it began to imitate the picture made by the camera. (Ivins 1953: 138) 
Shilling has argued for a perspective on the body which transcends the conventional dualism of nature and society. Drawing on Bourdieu and Elias as well as on Turner (1992) he proposes a philosophical anthropology which sees the human condition as rooted in a biology which is 'unfinished' so that human beings must necessarily complete themselves as cultural animals. Turner argues that the hand is a way into these matters for, as an aspect of human embodiment, it is a means by which, in the course of say child rearing, humans complete themselves and others and, through skilful manipulation, construct the environment which they inhabit. However, at the same time, the hand may be classified according to cultural rules and thus act symbolically as a source of meaningful power over others.

We might, therefore, provide an inclusive account of the hand as both body and society in a perspective on copying which connects the facts of human embodiment with social facts. Michael Taussig (1993) has, by means of cross cultural comparison, argued that mimesis is a human capacity which permits sociability through imitation. He argues that nature and culture are connected to each other neither by biological determinism nor by a one-sided social constructionism. Mimesis has two aspects for it is both imitation and relationship between the viewer and the viewed. It is a faculty which is developed, organized and transformed through specific forms of human culture and association: it is 'the nature that culture uses to create second nature, the faculty to copy, imitate, make models, explore difference, yield into and become Other' (Taussig 1993).

I suggest that we approach imitation in this way: as an aspect of the interdependence that arises from the unfinished nature of the human body and as a means by which human beings may reach out, to complete themselves in imitation of others and by means of the copy. Thus, the hand of the reproductive engraver might complete the original. Copying presupposes a faculty for imitation that must itself be always be given cultural direction if it is to be realized as a human capacity; it also presupposes classification and is, therefore, socially constructed. In that sense there is always an aspect to copying which is indeterminate and open and which is unspoken and there is always an aspect which is determined and closed.

At the heart of this is the indeterminacy of the copy -the potential for mimesis to flow in different and unpredictable directions and to find new associations. Classification interrupts and punctuates these flows of potential meaning. Yet, the world of copies cannot be definitively carved up according to a final system of technical and artistic classification. Ivins came close to identifying this indeterminacy when he coined the neologism the exactly repeatable pictorial statement' and when he specified the virtues of the collotype as a meta-language for illustrating his argument about the authority of half-tones.

Given Ivins's claims about the objectivity of the camera there are some curious features about the illustrations that he provided in support of his argument. His book is about the effects of photographs, more particularly half tones, yet the majority of its illustrations are collotypes. Collotype, an expensive, tricky method of photographic reproduction, gives a limited run and is capable of producing continuous tone (no intervening screen). Particularly suitable for the reproduction of delicate line work and washes, it was considered by Ivins to have virtues that were necessary for his book. He knew that most readers would be unfamiliar with the linear qualities and textures of handicraft reproductions and determined that collotype rather than half tone was appropriate for conveying them. The reader was to look at the illustrations in a way that half tones do not invite - to take the glass and recover something of the old connoisseur's sense of line, something that would have exposed the dots of a half tone screen. Collotypes, he observed, were to serve as a 'meta-language' for the visual syntax of the prints. Ivins required a word for copy and a means of illustration that evaded the prevailing judgments of taste concerning prints, which outflanked existing hierarchies and which caught the relations between different categories of printed images. It is that relational aspect of the copy which is important; Ivins sought both a word and an image that caught the conditions of existence of reproductions and originals. Yet, as I have argued elsewhere, Ivins's own book was an unwitting admission of the lack of photography's lack of objectivity (Fyfe 2000: 31-52).

Mimetic phenomena (originals, reproductions, translations, prints) are continually coming into being as a given regime of art classification exerts its authority in relation to the plenitude of the copy. The copy, or the exactly repeatable pictorial statement, is present in the interconnectedness of originals and reproductions. But it is difficult, as Ivins appreciated, to 
find a vocabulary of mimesis that is not already constituted according to a given regime of the copy. The difficulty is that classification punctuates meaning; it arrests the flow of discourse and channels things in one particular direction. That is why struggles over the classification of reproductions, such as that between painters and engravers, are of interest: they provide privileged moments for us to see into the social production of the difference between art and artefact and to witness the valorisation of that distinction as cultural capital.

\section{Conclusion}

Walter Benjamin, re-interpreting Marx's concept of the forces of production, focused on the destruction of aura, on the protean nature of aesthetic categories and the melting down of received art forms. Commentary, translation and pastiche have not always 'existed merely as minor exercises in the margin of literature (Benjamin 1973: 88). In the 'Storyteller' he argues that the novel has arisen out of the ruins of the art of storytelling from which it has abstracted the art of narrative:

The Art of storytelling is reaching its end... It is... a concomitant symptom of the secular productive forces of history, a concomitant that has quite gradually removed narrative from the realm of living speech and at the same time is making it possible to see a new beauty in what is vanishing (Benjamin 1971b: 87)

He tells us that story telling is an artisan's mode of communication which thrives in the milieu of craft work and which carries the marks of its making: 'The traces of the story teller cling to the story the way the handprints of the potter cling to the clay vessel'. Benjamin quotes Paul Valery on the waning of craftsmanship and the loss of the past:

Miniatures, ivory carvings, elaborated to the point of greatest perfection, stones that are perfect in polish and engraving... all these products of sustained, sacrificing effort are vanishing, and the time is past in which time did not matter (Benjamin 1970b: 93).

Pye was a storyteller who was reaching the end of the classical chapter in art reproduction. Like other engravers he was at the intersection of traditional and of modern classifications of reproductions; art history's grand narrative would submerge other ways of telling the story of art and other residual notions of creativity. Pye appeared at a moment of transition when the relationship between originals and reproductions had yet to disappear below the surface of things (Krauss 1986). Pye and his contemporaries, in claiming creativity for reproduction, showed that there are creative possibilities other than those which are sanctioned by modernism.

It is facile to conclude that artisan reproduction suffered inevitable extinction in the face of technical change. This misapprehension is rooted in a-historical understandings of twentieth-century photographic norms of perception which displaced nineteenth-century ideas about creativity in reproduction. Such attitudes are aspects of a teleological perspective which is challenged by revival of scholarly interests in the creative parts that copying and reproduction play in social life. The case of the artisan engravers allows us to recover a premodern culture of the copy; it illuminates a world in which the boundary between originals and reproductions was more permeable than that of our own and where the relationship between them was more visible than it is today. It suggests that our own culture of the copy has a social, as opposed to a merely technical, history and that there is an historical relationship between the museum and the photograph. Originals and reproductions are discursive objects in the sense that they are realizations of implicit cultural rules which, in any society, order the relationship between society and the copy.

Taussig argues that what is distinctive about the West is that mimesis has become a 'repressed presence' a practice which is 'distorted and used as a hidden force' (Taussig 1993: 45). My argument has been that the struggle between painters and engravers was a moment in that repression and that its outcome was linked to a mutation in cultural capital that valorized modernism. Modernism's notion of copying corresponds to a distinct culture 
of the senses for what is also repressed is the association between contact and imitation. Ours is a culture in which we expect copies to come after originals and to keep their distance.

The west's culture of copies, with its strong classification between originals and reproductions, is a particular social construction of our embodiment in the sense that it presupposes a mimetic faculty that will be transformed and channeled as a determinate culture of things. Our antinomian thinking in terms of 'originals' and 'reproductions' is merely one possible realization of a human capacity to imitate which is always transformed into a habitus or second nature. We might usefully place the story of English engravers in the context of the sociology of mimesis and of modernity's regulation of mimetic powers.

The sociology of art reproduction provides an opportunity to witness the primitive accumulation of cultural capital. Bourdieu argues, persuasively, that the legibility of a work of art presupposes cultural capital. I have tried to show, not only that the legibility of modern art presupposes the hidden history of the photographic gaze, but that it required a mutation that consigned the educated eye of engraving to the past. Finally, I have argued that a necessary though not sufficient condition of the formation of the cultural capital that was sanctioned as the love of art by the twentieth-century museum was extirpation and expropriation.

\section{Acknowledgements}

Earlier versions of this paper have been presented at the ESRC Museum and Society Seminar in 2000 (Award no: R4512646697) and at the Finnish Institute in 2002. I am grateful to Kevin Hetherington for his critical and constructive comments. I am also grateful to Mike Savage for so freely sharing his ideas on cultural capital with me. I have also had the benefit of discussions with Sharon Macdonald, Jim Maclaverty and Graeme Smart.

\section{Notes}

1 These arguments form part of a much wider corpus of writing and research by Bourdieu on the subjects of social theory, politics, culture and society, western and non-western cultures, art, literature and the historical sociology of cultural institutions such as museums. The argument about cultural capital is in part an historical one about changes in the character of social reproduction in advanced capitalist societies: that the shift from entrepreneurial to corporate capitalism, from personal to impersonal modes of economic possession and the development of the modern state have augmented the significance of cultural capital.

${ }^{2}$ In her Inaugural Lecture at Keele University (October 2002) Professor Pnina Werbner adroitly captures Bourdieu's analysis in these terms.

${ }^{3}$ Bourdieu reports survey data which determine whether or not visitors have a prior knowledge of works displayed and whether such knowledge is obtained from seeing originals or reproductions. They show that the middle class is disproportionately dependent on the second of these (Bourdieu and Darbel 1991: 150).

${ }^{4}$ I am not arguing that there is a single historical moment that marks the birth of cultural capital. What I am suggesting is that there are moments, perhaps spurts, in the formation of cultural capital which depend on a loss, confiscation or dilution of existing cultural monopolies.

${ }^{5}$ Max Weber provides insights into this transformation. He reflects on the character of early twentieth-century German university and the separation of labour, intellectual as well as manual labour, from the means of production. Large institutes such as medicine and science were state enterprises which required considerable concentrations of economic capital. Weber detects structural processes in common with more purely economic enterprises -that is the separation of the worker from his means of production:

This development, I am convinced will engulf those disciplines in which the craftsman personally owns the tools, essentially the library, as is still the case to a large extent in my own field. This development corresponds entirely to what happened to the artisan of the past and it is now fully underway (Weber 1948: 131). 
${ }^{6}$ Personal communication.

7100 Details may be an interesting side-light into the cultural and historical character of copying. In the first edition Clark notes that, whilst photographic detail had long been in use behind the scenes for scientific reasons, it was the Japanese critic Yukio Yashiro, writing on Botticelli, who first promoted it for the public appreciation in the early 1900s. In the 1990 edition Neil MacGregor observes that Clark was alert to the limitations of black and white photography, used in the first edition, on the grounds that it favoured linear over painterly qualities. MacGregor adds that black and white helped conceal the fact that in the 1930s London's National Gallery Collection was 'among the dirtiest in the world'.

${ }^{8}$ The first steps to the half-tone were taken, and perfected in the $1880 \mathrm{~s}$. Its principle is a breaking down of continuous tone into a mass of dots - accomplished by means of a cross line screen interposed between the image and a light sensitive printing surface. The effect is to translate tone into a pattern of dots which (with the exception of cruder newspaper pictures) normally appear to the eye as continuous tone.

${ }^{9} \mathrm{~A}$ burin is a tool for ploughing lines into copper or steel plates (see figure 9).

${ }^{10}$ See Fyfe (2000) and Fawcett (1982) for discussion of the notion that the engraver translated the picture.

${ }^{11}$ The 1953 edition differs from the later 1969 MIT reprint in that the reproductions for the latter are not as Ivins intended.

${ }^{12}$ All reasonable attempts have been made to trace copyright in the reproductions. For further discussion of his illustrations see Fyfe (2000).

${ }^{13}$ Academies were the focus of tensions and conflicts about engravers elsewhere -e.g. in the eighteenth-century French Academy (Dilke 1902). In France, as Johnson shows, reproductive engravers, such as Le Bas and Wille, had international reputations; they formed rival studios and had their artistic reputations publicly sealed the with so-called reception pieces (Johnson 1982). In Paris engravers were caught up in the cross fire between commercial interests and suffered status inconsistencies like those of the English (Dilke 1902:158-170). We hear of the 'the half veiled contempt' they experienced from the world, of how they 'chafed' at their inferior position within the Academy and of demeaning comparison with locksmiths.

${ }^{14}$ See Strutt (1785: 5) for an example of this view of engraving.

${ }^{15}$ In 1853, a new class of Academician Engraver was created. However, it was not until 1928 that the distinction between the two types of membership was finally eliminated. By then the power of the RA was weakening. At the end of the century engravers still appealed to old notions of authorship in reproduction. Process reproduction could not interpret: '[h]ow much of the beauty of these admirable cuts [wood engravings of Italian old masters] depends upon the temperament, the originality, the artistic skill, the "personal equation" ... of the man behind the graver' (The Century 1890: 312). Both in New York and in London, the claim that reproductive prints were creative had not been extinguished amongst collectors (Carey 1996: 214).

${ }^{16}$ Kubler (1962) and Weinsheimer, J. (1984) are pioneers in this respect.

17 The film, The Titan: Story of Michelangelo (1950), won an Academy Award as Best Documentary Feature and was produced by Robert Snyder. The critic James Agee described it as '... a new and exciting way to see some of the greatest work ever done.'

\section{References}

Anon (1770) Sculptura Historico-Technica: or the History and Art of Engraving (4th Edn). London: J.Marks. 
Benjamin, W. (1970a) 'The Work of Art in the Age of Mechanical Reproduction' in Illuminations, London: Jonathan Cape.

Benjamin, W. (1970b) 'The Story Teller' in Illuminations, London: Jonathan Cape.

Benjamin, W. (1973) 'The Author as Producer' in Understanding Brecht, New Left Books.

Bohrer, F. N. (2002) 'Photographic Perspectives: Photography and the Institutional Formation of Art History', in E. Mansfield (ed) Art History and its Institutions, London: Routledge.

Bourdieu, P. (1977) Outline of a Theory of Practice, Cambridge: Cambridge University.

Bourdieu, P., (1984) Distinction: A Social Critique of the Judgement of Taste, London: Routiedge and Kegan Paul.

Bourdieu, P. and Darbel, A. (with Schnapper, D.) (1991) The Love of Art: European Art Museums and their Public, Oxford: Polity Press.

Bourdieu, P. (1997) 'Three Forms of Capital' in A. H. Halsey, H. Lauder, P. Brown and A. S. Wells, (eds) Education: Culture, Economy and Society, Oxford/New York: Oxford University Press.

Calhoun, C. (1993) Critical Social Theory, Oxford: Polity Press.

Carey, F. (1996) 'Campbell Dodgson' in A. Griffths (Ed.) Landmarks in Print Collecting, London: British Museum Press.

Clark, K (1938/1990) 100 Details from Pictures in the National Gallery, London: Trustees of the National Gallery.

Connerton, P. (1989) How Societies Remember, Cambridge: Cambridge University Press.

Crimp, D. (1993) On the Museum's Ruins, Cambridge, MA: MIT Press.

Dilke, [E.F.S] (1902) French Engravers and Draughtsmen of the XVIIIth Century, London: George Bell and Sons.

Elias, N., (1978), The Civilizing Process; Vol. I 'The History of Manners', Oxford: Basil Blackwell.

Elias, N., (1982), The Civilizing Process; Vol. 2 'State Formation and Civilization', Oxford: Basil Blackwell.

Fawcett, T. (1982) 'On Reproductions', Art Libraries Journal, 7 (1) (Spring): 9-16.

Fisher, P. (1991) Making and Effacing Art, Cambridge, Mass: Harvard University Press.

Fox, Celina (1976) 'The Engravers' Battle for Professional Recognition in Early Nineteenth Century London', The London Journal, 2 (1).

Fyfe, G. J. (1973) The Social Context of English Engraving during the Nineteenth Century, University of Leicester (unpublished MPhil thesis).

Fyfe, G. J. (2000) Art, Power and Modernity, London: Continuum Books.

Gage, J. (1989) An Early Exhibition and the Politics of British Printmaking, 1800-1812, Print Quarterly, 6 (2) 123-39. 
Hambler, A. (1995) The Use of Photography by Nineteenth Century Art Historians' in H. E. Roberts (ed) Art History through the Camera's Lens, Amsterdam: Gordon and Breach.

Hambler, A. (1996) "A Higher Branch of the Art": Photographing the Fine Arts in England, 18391880, Amsterdam: Gordon and Breach.

Hetherington, K (1999) 'From Blindness to Blindness: Museums, Heterogeneity and the Subject' in John Law and John Hassard (eds) Actor Network Theory and After, Oxford: Basil Blackwell.

Hetherington, K. and Lee, N. (2000) 'Social Order and the Blank Figure', Environment and Planning D. Society and Space,18,169-184.

Honour, H. (1972) 'Neo-Classicism' in The Age of Neo-Classicism, London: Arts Council of Great Britain, (xxi-xxix).

Hyde, S. (2001) 'Print Makers and the Royal Academy Exhibitions, 1780-1836' in D. Solkin (ed) Art on the Line, London: Yale University Press.

Ivins, William M. (1953) Prints and Visual Communication, London: Routledge and Kegan Paul.

Johnson, W. M. (1982) French Royal Academy of Painting and Sculpture engraved reception pieces, 1672-1789, Kingston, Canada: Queen's University.

Jussim, E. (1983) Visual Communication and the Graphic Arts, New York and London: R. R. Bowker.

Krauss, R. E. (1986) The Originality of the Avant-Garde and Other Modernist Myths, Cambridge Mass: MIT Press.

Kubler, G. (1962) The Shape of Time: Remarks on the History of Things, New Haven and London: Yale University Press.

Landseer, J. (1807) Lectures on the Art of Engraving, London.

Lightbown, R. W. (1970) 'Introduction', in John Pye, Patronage of British Art, London: Cornmarket Press.

Malraux, A. (1967) Museum without Walls, London: Secker and Warburg.

Marx, K. (1954) Capital, volume 1, Moscow: Progress Publishers.

Pye, John (1970) [1845] Patronage of British Art, London: Cornmarket Press [London: Longman, Brown, Green, and Longmans]

Roberts, H. E. (1995) Art History through the Camera Lens, Amsterdam: Gordon and Breach.

Shilling, C. (1993) The Body and Social Theory, London: Sage.

Sousloff, C. M. (2002) 'Art Photography, History and Aesthetics' in E. Mansfield (ed) Art History and its Institutions, London: Routledge.

Taussig, M. (1993) Mimesis and Alterity: A Particular History of the Senses, London: Routledge. 
Tomkins, C. (1970) Merchants and Masterpieces: the Story of the Metropolitan Museum of Art, London and Harlow: Longman.

Turner, B. (1992) Regulating Bodies: Essays in Medical Sociology, London: Routledge.

Wacquant, L. (1996) 'Forward' in P. Bourdieu, The State Nobility, Oxford: Polity Press, (ix-xxii).

Weber, M. (1948) 'Science as a Vocation' in H. H. Gerth and C. Wright Mills (eds) From Max Weber: Essays in Sociology, London: Routledge and Kegan Paul.

Weinsheimer, J. (1984) Imitation, London: Routledge and Kegan Paul.

* Gordon Fyfe is a Fellow of Keele University where he was previously Senior Lecturer in Sociology. His publications include Theorizing Museums, Oxford: Basil Blackwell (1996) which he co-edited with Sharon Macdonald, and Art, Power and Modernity, London: Leicester University Press (2000). 